Condor 83:270-272

(C) The Cooper Ornithological Society 1981

\section{RANGE EXPANSION OF THE BRONZED COWBIRD WITH THE FIRST MISSOURI RECORD}

\section{MARK B. ROBBINS}

AND

\section{DAVID A. EASTERLA}

At the beginning of this century the Bronzed Cowbird (Molothrus aeneus) was found from southern Texas through Mexico and Central America to Western Panama (Ridgway 1902). Since then, the species has increased and expanded its range in the United States. The purpose of this note is to summarize this expansion and to discuss its possible consequences on bird populations in the United States.

\section{RANGE IN THE UNITED STATES}

Arizona. The Bronzed Cowbird was first observed in Arizona in 1909 (Phillips et al. 1964) and breeding populations of the species apparently became established throughout much of southern Arizona during the next 45 years. In 1957, the A.O.U. Check-list indicated that the winter range extended "north, rarely to southern Arizona (Tucson)" (p. 542). Bronzed Cowbirds were not reported west of Wickenburg (Maricopa Co.) until 1951 when Monson (1954) found them along the Colorado River near Parker (Yuma Co.). By the mid-1960's, they were regular but uncommon winter residents of southern Arizona (Johnson and Roer 1968). The species now commonly breeds throughout southern and central Arizona (M. Robbins, pers. observ.), but is still an uncommon summer resident along the Colorado River (J. Dunn, pers. comm.). Wanderers have also recently appeared in Prescott (Yavapai Co.), Carrizo (Navajo Co.), and Clifton (Greenlee Co.) (Witzemann et al. 1976).

New Mexico. Phillips et al. (1964) indicated that Bronzed Cowbirds first appeared in New Mexico, in Guadalupe Canyon (Hidalgo Co.), during July 1947. The species was breeding there on 21 June 1968 (Niles 1970). It was primarily confined to the extreme southwestern corner of the state until the early 1960's, when it was detected in the Gila River Valley near Redrock (Grant Co.) on 6 June 1962. By 1968, it had reached the Cliff area (Grant Co.) and was subsequently found breeding just north of there (Hubbard 1971). The species was observed in the San Francisco Valley near Pleasanton (Catron Co.) on 10 June 1975 (Witzemann et al. 1975); in central New Mexico at the Bosque National Wildlife Refuge (Socorro Co.) on 6 June 1973 (Parker 1973); and again in the Socorro area during May 1977 (Witzemann et al. 1977). At present, its range continues to expand slowly northward in the state.

California. The first report of the Bronzed Cowbird in California was of a male at Whipple Point above Parker Dam (San Bernardino Co.) on 29 May 1951 (Monson 1951). Monson (1958) obtained the first specimen near Bard (Imperial Co.) on 12 May 1955. Cardiff (1961) collected a second specimen, a female, about $110 \mathrm{~km}$ farther west, at Westmoreland (Imperial Co.) on 22 April 1956. Cowbirds were reported at Brock Ranch (Imperial Co.) on 10 May 1968 and at Mecca in the desert north of the Salton Sea (Riverside Co.) on 13 July 1968. A pair lived near Jacumba (extreme southwestern San Diego Co.) between 1973 and 1976, but their breeding status is uncertain; however, a juvenile was seen there on 13 July 1974 (J. Dunn, pers. comm.). Strays were seen as far west as Whittier (Los Angeles Co.) on 12 June 1963 and 9 April 1964 (J. Dunn, pers. comm.); and as far north as Kelso (San Bernardino Co.) on 25 May 1977 (McCaskie 1977).

McCaskie et al. (1966) provided the first evidence that Bronzed Cowbirds were breeding in California when they saw a pair copulate near Laguna Dam (Imperial Co.) on 2 June 1962. Currently, the species is an uncommon summer resident along the Colorado River, primarily in park-like settings (J. Dunn, pers. comm.).

Texas. In the early 1900's, the Bronzed Cowbird was restricted to the lower Rio Grande Valley. Its range increased significantly in southern Texas after the Great Freeze of 1951, when most of the remaining forest was cleared for agriculture (Oberholser 1974). The earliest record of its presence in the Big Bend area (Brewster Co.) dates 9 June 1969 (Easterla and Wauer 1972). In July 1970, at least two young cowbirds were in the company of Hooded (Icterus cucullatus) and Orchard orioles (I. spurius) at this same locality (Snider 1970). The species also appeared in the Davis Mountains (Jeff Davis Co.) of West Texas during the summer of 1969 (Easterla and Wauer 1972), and large numbers were there during the summer of 1973 (Parker 1973). By 1972, the species was breeding as far north as San Angelo (Tom Green Co.; Williams 1972). Wintering individuals occasionally appear as far north as Brazos Co. and east to Houston (Texas Ornithol. Soc. 1974). There is also a probable record for Fort Worth (Tarrant Co.; K. Arnold, pers. comm.).

Louisiana. R. B. and M. A. Moore et al. observed six Bronzed Cowbirds at Little Cheniere (Cameron Parish), Louisiana on 31 December 1961. The first specimen collected in Louisiana was obtained on 14 March 1964 just west of Port Allen (West Baton Rouge Par.; Lowery 1974); this specimen is in the State University Museum of Zoology (LSUMZ 33861). All subsequent records have been confined to the extreme southern parishes. An additional specimen of unknown sex (LSUMZ 94224) was taken at Belle Chasse (Plaquemines Par.) on 11 August 1978. Although this species may have bred in New Orleans as early as 1974, positive evidence of this was not obtained until 1976 (Stewart 1976). The number of breeding individuals in the New Orleans area has increased steadily since then (N. Newfield and others, pers. comm.).

Florida. The first record was of three birds in Sarasota (Sarasota Co.) on 15-21 April 1962 (Paulson and Stevenson 1962). Matteson (1970) subsequently collected a male on 8 November 1968 at Lake Alice (Alachua Co.) in northern Florida. Additional specimens were seen or obtained in southeastern Florida (Alachua Co.) on 18 November 1971 (Robertson 1972) and at Boynton Beach (Palm Co.) on 7 and 11 November 1976 (Edscorn 1977). An "invasion" of cowbirds followed in south Florida during the winter of 1977-78, where as many as ten may have been present (Stevenson 1978); three wintered near St. Petersburg (Pinellas Co.) during 1978-79 (Stevenson 1979). To date there is no evidence of breeding in the state.

Mississippi. Bronzed Cowbirds were first noted in Mississippi on 6 January 1979 at Pascagoula River Flats (Jackson Co.). In March, more than 15 were seen in huge flocks of blackbirds (Hamilton 1979).

Missouri. Berlin Heck first reported the presence of a Bronzed Cowbird in Missouri on 5 January 1979 at a bird feeder in the Squaw Creek National Wildlife Refuge (Holt Co.). We and others (Tim Barksdale, Leo 
Galloway, and Floyd Lawhon) saw the bird later. It was subsequently collected by Heck and found to be a female of the nominate race M. a. aeneus (D. A. Easterla 3094; ova $1 \mathrm{~mm}$; some fat; light head molt; weight $59 \mathrm{~g}$ ). This was either a stray individual or represents a range extension of about $830 \mathrm{~km}$ north of the nearest locality where it was reported earlier (Fort Worth, Texas).

\section{DISCUSSION}

As with a number of other species currently expanding their ranges [e.g., Cattle Egret (Bubulcus ibis), Whitetailed Kite (Elanus leucurus), Burrowing Owl (Athene cunicularia), Great-tailed Grackle (Quiscalus mexicanus), and Brown-headed Cowbird (Molothrus ater)], the Bronzed Cowbird appears to be taking advantage of human alteration of the environment. All of the above species have increased dramatically in the United States as a result of increased agricultural activity (Davis 1960, Ligon 1963, Mayfield 1965, Eisenmann 1971, Pratt et al. 1972). For example, the Bronzed Cowbird increased significantly in Texas after large tracts of forest along the Rio Grande Valley were cleared for agriculture. This seems to have paved the way for its expansion into central Texas and along the Gulf Coast.

The irrigation of arid land has undoubtedly aided expansion of the species in the southwest by providing an abundant, year-round source of food. This species commonly forages in residential areas, golf courses, and parks in central and southern Arizona (M. Robbins, pers. observ.). It has also taken advantage of the increased presence of cattle by feeding on insects flushed by them. Thus far, it has had more limited success in the drier areas of Arizona and California.

Like the Brown-headed Cowbird, the Bronzed Cowbird is a brood parasite (Bent 1958). The adverse effects of the Brown-headed Cowbird on a number of North American birds are well documented (Southern 1958, Walkinshaw 1961, Mayfield 1977). The range expansion of another brood parasite in the United States may result in even more dramatic declines in some species. These two cowbirds apparently parasitize different hosts to some extent in areas where they are sympatric, M. aeneus preferring larger species (especially Icterus) and M. ater smaller ones (vireos, warblers) (Friedmann et al. 1977). Although this may lessen competition between the two congeners, there is still a significant overlap in the species that they parasitize (Friedmann et al. 1977).

Little information exists concerning the effect of Bronzed Cowbirds on other birds. They may have contributed to the decline of several species of wrens, vireos, and warblers in Texas (Oberholser 1974), but no quantitative evidence of this has been published. Careful documentation of their range extensions and possible effects on other species will be useful in studying both the mechanics of range expansion and the coevolution of parasitic birds and their hosts.

We thank K. Arnold, J. V. Remsen, Jr., and M. D. Williams for comments on the manuscript.

\section{LITERATURE CITED}

American Ornithologists' Union. 1957. Checklist of North American birds. Fifth ed. Am. Ornithol. Union, Baltimore.

BENT, A. C. 1958. Life histories of North American blackbirds, orioles, tanagers, and allies. U.S. Natl. Mus. Bull. 211.

CardifF, E. A. 1961. Two new records of birds for California and notes on species of the Imperial Valley and Salton Sea area of California. Condor 63:183.
DAvis, D. E. 1960. The spread of the Cattle Egret in the United States. Auk 77:421-424.

Easterla, D. A., AND R. Wauer. 1972. Bronzed Cowbird in West Texas and two bill abnormalities. Southwest. Nat. 17:293-312.

Edscorn, J. B. 1977. Florida region. Am. Birds 31:169.

EisenmanN, E. 1971. Range expansion and population increase in North and Middle America of the White-tailed Kite (Elanus leucurus). Am. Birds 25:529-536.

FriedmanN, H., L. Kiff, and S. I. Rothstein. 1977. A further contribution to knowledge of the host relations of the parasitic cowbirds. Smithson. Contrib. Zool. 235.

Hamilton, R. B. 1979. Central southern region. Am. Birds 33:290.

HubBard, J. P. 1971. The summer birds of the Gila Valley, New Mexico. Nemouria 2.

Johnson, R. R., AND B. RoER. 1968. Changing status of the Bronzed Cowbird in Arizona. Condor 70: 183 .

LIGON, J. D. 1963. Breeding range extension of the Burrowing Owl in Florida. Auk 80:367-368.

LOWERY, G. H., JR. 1974. Louisiana birds. Louisiana State Univ. Press, Baton Rouge.

Matteson, R. E. 1970. Bronzed Cowbird taken in Florida. Auk 87:588.

MAYFIELD, H. 1965. The Brown-headed Cowbird, with old and new hosts. Living Bird 4:13-28.

Mayfield, H. 1977. Brown-headed Cowbird: agent of extermination? Am. Birds 31:107-113.

McCaskie, G. 1977. Southern Pacific region. Am. Birds 31:1049.

McCaskie, G., R. Stallcup, and P. DeBenedictis. 1966. Notes on the distribution of certain icterids and tanagers in California. Condor 68:596-599.

Monson, G. 1951. Southwest region. Audubon Field Notes 5:271.

Monson, G. 1954. Westward extension of the ranges of the Inca Dove and Bronzed Cowbird. Condor 56:229-230.

Monson, G. 1958. Reddish Egret and Bronzed Cowbird in California. Condor 60:191.

NiLES, D. M. 1970. A record of clutch size and breeding in New Mexico for the Bronzed Cowbird. Condor 72:500.

Oberholser, H. L. 1974. The bird life of Texas. Univ. of Texas Press, Austin.

PARKER, T. 1973. Southwest region. Am. Birds 27:905.

Paulson, D. R., AND H. M. Stevenson. 1962. Florida region. Audubon Field Notes 16:403.

Phillips, A., J. Marshall, AND G. Monson. 1964. The birds of Arizona. Univ. of Arizona, Tucson.

Pratt, H. D., B. Ortego, and H. D. Guillory. 1972. Spread of the Great-tailed Grackle in southwestern Louisiana. Wilson Bull. 89:483-485.

RidgWAY, R. 1902. The birds of North and Middle America. Bull. U.S. Natl. Mus. 50:1-834.

Robertson, W. B., JR. 1972. Florida region. Am. Birds 26:53.

SNIDER, P. R. 1970. Southwest region. Audubon Field Notes 24:705.

Southern, W. M. E. 1958. Nesting of the Red-eyed Vireo in the Douglas Lake region, Michigan. JackPine Warbler 36:104-130.

Stevenson, H. M. 1978. Florida region. Am. Birds $32: 342$.

Stevenson, H. M. 1979. Florida region. Am. Birds $33: 276$.

Stewart, J. R. 1976. Central southern region. Am. Birds 30:968.

Texas Ornithological Society. 1974. Checklist of 
the birds of Texas. Texas Ornithol. Soc., College Station.

WALKINSHAW, L. H. 1961. The effect of parasitism by the Brown-headed Cowbird on Empidonax Flycatchers in Michigan. Auk 78:266-268.

Williams, F. 1972. Southern Great Plains. Am. Birds 26:874.

Witzemann, J., J. P. Hubbard, and K. Kaufman. 1975. Southwest region. Am. Birds 20:1018.

Condor 83:272-273

(C) The Cooper Omithological Society 1981

\section{FIRST RECORD OF A BLACK-LEGGED KITTIWAKE IN IDAHO}

\section{JOHN W. CONNELLY}

AND

ROBERT J. GATES

The Black-legged Kittiwake (Rissa tridactyla) is a common oceanic gull that winters off the Pacific coast from British Columbia south to northwestern Baja, California (A.O.U. Check-list 1957). While there have been several inland reports of Black-legged Kittiwakes in various western states (Haywood et al. 1976, Weber and Larrison 1977, and others), to our knowledge this species has never before been reported in Idaho. The purpose of this note is to document the first record of this species in Idaho and to review past records of the kittiwake in adjacent states.

The carcass of a juvenile male Black-legged Kittiwake was found by the authors on 13 February 1980 , approximately $5 \mathrm{~km}$ southeast of Howe, Butte Co., Idaho. The nearest large body of water is American Falls Reservoir, located on the Snake River, $85 \mathrm{~km}$ to the southeast. This bird appeared to have been dead less than $24 \mathrm{~h}$. A large wound on the dorsal portion of the body, just behind the neck, indicated that the bird
Witzemann, J., J. P. Hubbard, and K. Kaufman. 1976. Southwest region. Am. Birds 30:989.

Witzemann, J., J. P. Hubbard, and K. Kaufman. 1977. Southwest region. Am. Birds 31:1034.

Museum of Zoology, Louisiana State University, Baton Rouge, Louisiana 70893. Address of second author: Department of Biology, Northwest Missouri State, Maryville, Missouri 64468. Accepted for publication 19 November 1980. may have been killed by a raptor. The carcass weighed $277.5 \mathrm{~g}$ and contained no deposits of body fat.

Most of the inland sightings of Black-legged Kittiwakes in the northwestern United States have been made in the last eight years (Table 1). It is unclear whether this recent increase in sightings is the result of greater effort by field biologists, or if it results from a pioneering tendency of the kittiwake due to an increase in the number of reservoirs along major northwestern rivers. Juvenile gulls of many species wander great distances in the late summer and fall (Pettingill 1970, Parsons and Duncan 1978). Since at least one of the records was for an adult and most of the sightings occurred during the winter and early spring, this does not immediately offer a satisfactory explanation for the majority of inland kittiwake records. Further, the sightings of kittiwakes do not follow the same pattern as those of the Ancient Murrelet (Synthliboramphus antiquus; Munger 1965); Munger indicated that murrelets wander inland primarily during October and November, and their movements are associated directly or indirectly with adverse weather over the Pacific coast. However, we found that at least one and usually a series of low pressure systems had moved inland across the Pacific Northwest within a two- to three-week period just before each inland kittiwake sighting (U.S. Dep. of Commerce) except for the 1898 sighting, for which we have no data. We suggest that inland movements by the Black-legged Kittiwake are often the result of winter storms moving inland from the Pacific coast.

TABLE 1. Inland records of Black-legged Kittiwakes in the northwestern United States.

\begin{tabular}{|c|c|c|c|}
\hline Area & Time of sighting & Age of bird & Authority \\
\hline \multicolumn{4}{|l|}{ Eastern Washington } \\
\hline Potholes Reservoir & January 1972 & adult $^{b}$ & Verner 1974 \\
\hline Asotin County & February 1976 & unknown ${ }^{b}$ & Weber and Larrison 1977 \\
\hline \multicolumn{4}{|l|}{ Southeastern Idaho } \\
\hline Butte County & February 1980 & immature $^{\mathrm{c}}$ & this report \\
\hline \multicolumn{4}{|l|}{ Western Montana } \\
\hline Ninepipe N.W.R. ${ }^{a}$ & April 1977 & immature $^{\mathrm{c}}$ & P. D. Skaar (pers. comm.) \\
\hline Fort Peck Reservoir & December 1978 & immature $^{\mathrm{b}}$ & P. D. Skaar (pers. comm.) \\
\hline \multicolumn{4}{|l|}{ Utah } \\
\hline Fish Springs N.W.R. & March 1972 & unknown ${ }^{c}$ & Haywood et al. 1976 \\
\hline \multicolumn{4}{|l|}{ Wyoming } \\
\hline Near Douglas, Wyoming & November 1898 & unknown $^{\mathrm{c}}$ & McCreary 1937 \\
\hline
\end{tabular}

a National Wildlife Refuge

"S Sighting. 